\title{
Work environment and the performance of forest rangers in South West Mau Forest, Kenya
}

\author{
NDUKU ISSA ETEMESI", PETER K. SIRMAH, JOSIAH CHEPKWONY \\ Department of Forest, School of Natural Resources and Environmental Management, University of Kabianga. P.O. Box 2030, Kericho, Kenya. \\ Tel.: +254716188311, `email: esirnduku@gmail.com
}

Manuscript received: 24 August 2018. Revision accepted: 13 September 2018.

\begin{abstract}
Etemesi NI, Sirmah PK, Chepkwony J. 2018. Work environment and the performance of forest rangers in South West Mau Forest, Kenya. Asian J For 2: 46-53. Forest protection requires strong governance in the implementation, compliance and enforcement of laws and policies. This can only be achieved if personnel responsible for such duties are equipped with good working environment. The objective of this research was to evaluate and understand how the working environment of forest rangers under Kenya Forest Service (KFS) affects their performance. The Rangers, under the Enforcement and Compliance Division (ENCOM) of KFS, are mandated to implement the enforcement of laws and policies pertaining to forests and their allied resources as prescribed in the Kenya Forest Act of 2005. Qualitative research approach was employed in the data collection by the use of structured questionnaires in four forest stations, namely three stations in Londiani, Masaita, and Sorget of Kericho Zone, Mau complex, and one station in the Kericho Ecosystem Conservator's Office. From a total of 46 rangers deployed in the four stations, 32 rangers were sampled randomly, 8 serving in each of forest stations. A pre-tested questionnaire on demographic trends, duration of service, work environment variables constituting remuneration, living conditions, motivation, appraisals, rewards, empowerment, communication, work tools, mobility, uniforms, challenges, and personal life were administered in January 2016. The performance indicators gave dissatisfaction rates of 59\% and 63\% in most of the parameters tested. Comparison of the finding of this study with the findings of the surveys of 2010 and 2013 in different conservancies in Kenya gave an index of $51.4 \%$ and $56.74 \%$ satisfaction respectively. The results, therefore, denote a progressive correlation between the working conditions drivers and the performance of forest rangers. More radical measures must be undertaken to enhance the performance and productivity of rangers through motivation, improving both their intrinsic and extrinsic working environment.
\end{abstract}

Keywords: ENCOM division, forest rangers, working conditions, working performance

\section{INTRODUCTION}

Escalated climate change and degradation of natural resources in the last two decades have encouraged societies across the world to put more attention on governance as well as the implementation, compliance and enforcement of natural resource policies and laws. In the context of climate change mitigation, Warchol and Kapla (2012) note that forestry is one of the key sectors where policies and laws should be enforced. Ultimately, sustainable forest management demands a balance among conservation, regeneration, management, governance, enforcement, and implementation programs (Koontz 2007).

Kenya holds high level of diversity in flora and fauna in its forests, which stretch from the mangroves in the coastal regions to tropical and dry forests (Gichora and Bargerei 2015). Forests offer a myriad of services and products such as eco-tourism, water catchment towers, habitat for wildlife, provision to timber, firewood, and other nonforest products which significantly contributes to the improvement of the livelihood of the forest adjacent communities and a key contributor to the national GDP (Onyango 2013).

Kenya like other parts of the world faces an alarming rate of forest destruction and degradation; over 12,000 hectares of forests are lost yearly due to conversion of forest land to agriculture and other development projects (Kenya Forest Service 2010). Subsequently, considerable extents of forests have continually degraded due to illegal logging, unsustainable utilization, uncontrolled grazing, pole making, and charcoal making (Envag Associates 2013; Onyango 2013; Mathu 2007). Demand for energy is a critical proponent for the exacerbated destruction of forest as more than $70 \%$ of national energy is derived from fuelwood and charcoal that is often illegally extracted from forests (Kenya Forest Service 2010). As per the JulySeptember 2014 Kenya Forest Service (KFS) report, Kenya's forest cover was estimated $6.99 \%$ (indigenous forests, plantations, woodlands, and mangroves) which dropped from the initial $12 \%$ cover as a result of unsustainable and illegal exploitation of the resource.

In order to curb the exacerbating rates of destruction of forest resources, more radical measures need to be adopted (Mathu 2007; Kimani 2012; Onyango 2013). Under the Kenya Vision 2030 goals, KFS aims to attain a minimum of $10 \%$ forest cover (Kenya Forest Service 2010). Establishment of forest enforcement and compliance division is therefore an inevitable option so that the forest resources in Kenya can be protected from degradation (Kimani 2012). Under the Forest Department, the mandate of forest protection as well as law compliance and enforcement is bestowed to the forest guards currently 
referred to as the Forest Rangers under the Forest Act 2005 (Kenya Forest Act 2007; Kenya Forest Service 2012).

In Kenya, the forest rangers fall under the Enforcement and Compliance (ENCOM) Division established in February 2007 through the Forest Act 2005, which reformed the Forest Department to Kenya Forest Service (Kimani 2012). Under Part V of the Act, the commissioned officers (forest rangers) are mandated to implement and enforce policies and laws pertaining to forests and their allied resources with reference to the prescriptions in the Forest Act (Kenya Forest Act 2007) which was amended to Forest Conservation and Management Act 2016 in September 2016. In addition to the compliance and enforcement of forestry regulations, the officers also provide guidance and supervision in forest management such as forest harvesting, planting, and firefighting; intelligence, inspection, and prosecution of forest offenders; as well as provision of skills and manpower where needed (Kenya Forest Act 2007; Kenya Forest Service 2010). These responsibilities match those of forest rangers and conservation officers in many regions of the world, such as South Africa and United States of America, where the officers take an active role in the law enforcement through crime investigation, arrest of offenders, preparation of cases for court and testifying at trial among others (Warchol and Kapla 2012; Koontz 2007). The ENCOM Division has more than 2500 officers posted in the 210 forest stations and other administrative posts (Envag Associates 2013). They work hand-in-hand with the professional and technical cadre of the Service, forest adjacent communities and other environmental agencies and organizations in their areas of jurisdiction (Kenya Forest Service 2010; Envag Associates 2013). The expected responsibilities are a clear ground for the ENCOM division to upscale its performance; a deliberation that KFS itself must ensure the rangers is capacitated with an ambient and amiable environment from which they can laconically partake their enforcement and compliance duties.

Forest rangers in Kenya and globally play an imperative role in the protection, management, and conservation of forest resources and biodiversity (Eliason 2006; Mathu 2007; Kimani 2012; Warchol and Kapla 2012; New York State Department of Environmental Conservation 2012). The state and condition of forests greatly depend on the ability of the protection agencies to implement their duties amicably and effectively. Mathu (2007) argues, no matter how good policy or law may be; the policy is prone to failure if the enforcement, compliance and implementation measures of the policy are substandard and equivocal. Mathu (2007) and Koontz (2007) further state that enforcement and compliance division in forestry department experiences considerable challenges that potentially inhibit the policy and law enforcement. Some of the noted challenges constantly being faced by forest rangers include poor working conditions, feeble and inadequate structural capacities, inadequate working facilities and equipment, and low morale and motivation (Mathu 2007; Koontz 2007; Kimani 2012; Onyango 2013). These drivers are greatly manifested in the dire calls for promotion of protection, management, and conservation of forests and allied resources (Onyango 2013). Such problems need to be solved by improving the working condition of the rangers (Drizin 2003; Harter et al. 2004).

Working environment affects the productivity, effectiveness and efficiency of any workforce (Oswald 2012; Anderson 2013; Harter et al. 2004). In order to improve the performance of the workforce, it is essential to understand and acknowledge the factors influencing its productivity and efficacy (Harter et al. 2004, Oswald 2012). Kehoe and Wright (2010) note that the working conditions directly affect the morale of the employees; therefore, poor working conditions significantly impede the productivity of any workforce. It is of no exception that the rate of dissatisfaction index recorded in this study inhibits the Rangers' performance. The achievement of the Kenya Forest Service (KSF) objectives and vision rests on the collective ability of all the divisions of the Service and other stakeholders to undertake efficiently their duties (Koontz 2007; Kimani 2012).

This study aimed at evaluating the magnitude at which the working condition implicates the performance of forest rangers. Using the data derived from the questionnaires, the study, therefore, investigated how remuneration rates and motivation, living conditions, transport facilities, and working equipment, workplace discrimination and workpersonal life balance of the rangers implicate their work productivity.

\section{MATERIALS AND METHODS}

\section{Study area}

This study was carried out in Londiani, Sorget, and Masaita forest stations, and the Kericho Ecosystem Conservators base in Kericho Zone in Mau complex, Kenya. The four forest stations are under the protection of 46 forest rangers and 2 inspectors, 1 located at the Kericho Ecosystem Conservators office in located Masaita Forest Station and the other at Londiani Forest College based in Masaita Forest Station. Kericho Zone is of strategic importance to Kenya Forest Service since it houses the only forest rangers paramilitary training situated at Londiani Forest College, in the Masaita Forest station. This was critical for the study being the base from which all the forest rangers in the country are trained; hence, it was anticipated that the concerns and needs of the rangers within the location would be much less.

\section{Sampling}

The methodology used was based on the qualitative research approach by the use of questionnaires and analyzed using descriptive statistics. Pre-tested questionnaires were administered to 32 out of the 46 forest rangers serving in Sorget, Londiani, Masaita forest stations, and Kericho Ecosystem Conservator station. According to Krejcie and Morgan (1970) as designed in Morgan's table of determining sample size, out of the 40 targeted forest rangers, only 32 accepted to take part in the research, hence a deviation of 8 as per Morgan's table sample size. 


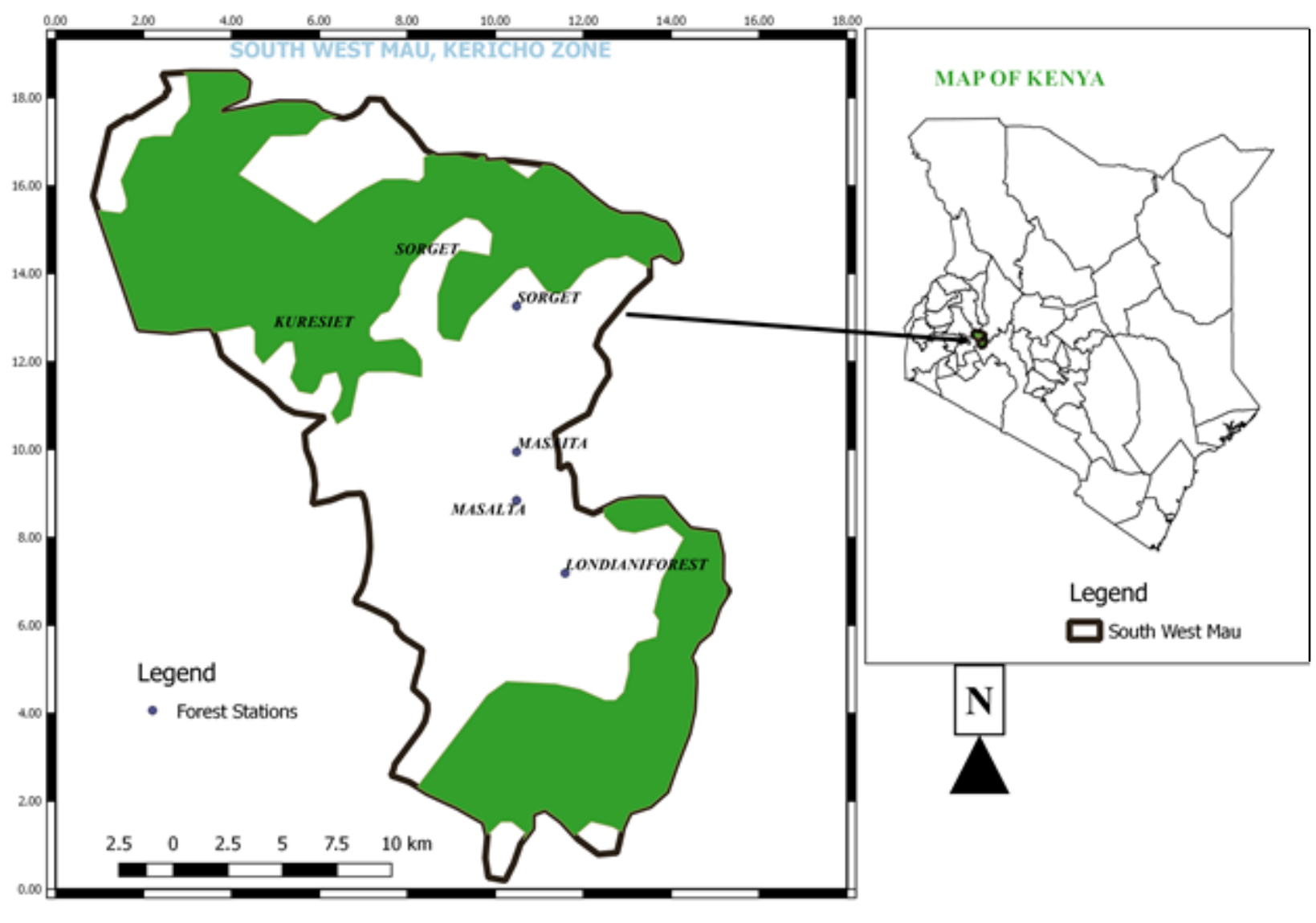

Figure 1. A map of the sampled stations in South West Mau, Kericho Zone, Kenya

\section{Questionnaire administration}

The pretested self-administering questionnaires were distributed to the 32 forest rangers who took part in the study. The questionnaires were designed to assess (i) the demographic characteristics \{gender, age range, marital status, and work experience $\}$ of the workforce and (ii) the drivers of work productivity. The parameters of work productivity examined consisted of the (i) remuneration rates \{salaries, job appraisal and promotion\}; (ii) workplace motivation \{work motivation, communication, and work performance, stress freeness of the working environment and supervisor motivation \}; (iii) sensitivity of KFS to rangers needs and wants \{wants, needs, and treammwork\}; (iv) quality of working facilities and equity $\{$ transport, working equipment, uniforms, living conditions, and discrimination $\}$ and (v) work-personal life balance \{balance and freeness with supervisors\}. The questionnaires were collected on the third day after being issued to the respondents.

\section{Data analysis}

The questionnaires were cross-examined to ascertain their accuracy, uniformity, and completeness. It was necessary to ascertain the responses before organization and coding to remove incomplete questionnaires to increase the accuracy. The questionnaires were then organized, numbered, and coded using the Statistical Package for Social Scientists (SPSS) version 22. The data was then analyzed using descriptive statistics and represented in frequencies and percentages using charts and tables to validate the relationships between the different variables. The results were analyzed and interpreted in frequency distribution tables.

\section{RESULTS AND DISCUSSIONS}

\section{Demographic trends of forest rangers}

The demographic data of the forest rangers were assessed to know the work diversity of the officers as the diversity in any workforce is attributed to sustainable and improved performance through sharing of experiences and skills. Gender is one of the prime indicators of work diversity of which the Kenya Constitution (2010) under Article 27 (8) categorically states, "The State shall take legislative and other measures to implement the principle that not more than two-thirds of the members of elective or appointive bodies shall be of the same gender". The law demands that a gender balance of workers within its parastatals as well. Out of the 32 respondents who took part in the study, forest rangers were $75 \%$ male and $25 \%$ female. It is important to verify the balance in the 
distribution of gender and age in the workforce; this affirms the relationship in the workforce and adheres to the gender-balance call as per the Kenya Constitution.

Ageism is one of the imperative outliners of work diversity. Thomas et al. (2014) state that age is organizing principle and an embodied identity as well as signifier of the richness and stability of a workforce in contemporary society. They note that age distribution significantly influences the material effect of the organization affecting both the individuals and organizations productivity. Thomas et al. (2014) study recommended for an age balance in any workforce to ensure flexible, energized, dependable, and sustainable transition in the workforce. The age diversity in this study presented skewed and formidable distribution index. Majority of the ranger (over two-thirds) fall under the age of 31 to 44 years old (Table $1)$.

The distribution imbalance in age might posses a danger in terms of transition of responsibilities and experiences. Envag Associates (2013) attributes the skewness to the long and inconsistent recruitment of forest rangers; it is a challenge and raises alarms for the sustainability of the workforce in the next 15 years if more rangers are recruited. The ENCOM Division is dominated by progressive old age lacking youthfulness in that only $12 \%$ of the rangers are aged 18-24 and 25-30. The age of $31-44$ is the majority of the forest rangers. Therefore, a balance of the workforce is crucial for sustainable performance of the forest rangers.

The experience of the workplace viably denotes its diversity and stability (Anderson 2013). Just like age, the experience of the employees promotes organizational sustainability, re-energizing the workforce through the integration of skills and experiences of the young and older employees. The research asked the respondents regarding the duration they have worked with ENCOM Division. It is noted about half of the rangers have worked with the division for at least 10 and 20 years. The experience is relatively balanced, unlike the age.

Table 1. Distribution of age range of the respondents

\begin{tabular}{lc}
\hline Age range & $\%$ \\
\hline $18-24$ & 12 \\
$25-30$ & 12 \\
$31-44$ & 72 \\
50 and above & 4 \\
\hline
\end{tabular}

Table 2. Distribution of working experience of the respondents

\begin{tabular}{lc}
\hline Forest rangers duration of service (years) & $\boldsymbol{\%}$ \\
\hline $1-5$ & 22 \\
$6-10$ & 26 \\
$11-15$ & 37 \\
$16-20$ & 8 \\
$21-25$ & 4 \\
$26-30$ & 3 \\
\hline
\end{tabular}

\section{Impacts of remuneration rates on the working performance \\ Remuneration rates and job appraisals}

According to a report on strengthening of the forest law enforcement and governance by the World Bank (2006), it is of critical importance for the initiation of institutional reforms of forest law enforcement agencies. The report conjectures on the vitality of the forest management agencies to acknowledge and understand the role of incentives such as the salary structures and job appraisal among others on the productivity of its officers. Many studies have been conducted to evaluate the magnitude at which remuneration affects the performance of employees; many have diverse findings (Van Herpen et al. 2005; Oswald 2012; Warchol and Kapla 2012; Kimani 2012; World Bank 2006; Onyango 2013).

The findings of the study indicated that the forest rangers were equally dissatisfied with the current remuneration rates, job appraisal and promotion measures implemented by the Service. On both the remuneration and job appraisal questions, the rangers were 59\% dissatisfied with the salaries and promotion structures (Table 3). This implies that a great magnitude of the ranger performance was influenced by these factors. Van Herpen et al. (2005) argue that even though salaries and job promotions do not directly depict the working environment, salaries are a crucial element of extrinsic motivation while job appraisal favors intrinsic motivation. Motivation levels are noted to significantly implicate work productivity, as Warchol and Kapla (2012) argue in their study that low salaries often contribute to escalated dissatisfaction rates and low motivation among South African law enforcement and conservation officers. The low motivation is likely to induce them to the vices of corruption and bribery, low patrol frequencies, feeding offenders with critical information about the richness of the forests and where to find high-quality fauna and flora (Warchol and Kapla 2012). Consequently, Kimani (2012) explained that even though it is common parlance and belief that meager salaries promote the low motivation manifested by corruption, salaries and job appraisal alone are not sufficient to spur the performance of the rangers, rather the integrated improvement of both the motivation factors and the working conditions. Onyango (2013) equally notes that high and long-term performance of employers is promoted by stable remunerations, promotion measures, and work environment; these facts are determinants for better productivity.

Table 3. Level of satisfaction of rangers on remuneration rates, and job appraisal and promotions incentives.

\begin{tabular}{lcc}
\hline \multicolumn{1}{c}{ Rangers response } & Salaries (\%) & $\begin{array}{c}\text { Job appraisals and } \\
\text { promotion \% }\end{array}$ \\
\hline Strongly Disagree & 4 & 0 \\
Disagree & 55 & 59 \\
Strongly Agree & 11 & 18 \\
Agree & 26 & 19 \\
Don't know & 4 & 4 \\
\hline
\end{tabular}


Job appraisal is projected towards promoting the intrinsic needs of the workforce, motivating them to upgrade and transcend their duties (Van Herpen et al. 2005). An employer that recognizes the efforts of employees motivates them to upscale their efforts, which manifests in cumulative productivity. In the 2010/2011 KFS annual report, 41 vehicles were impounded by rangers; 262 forest offenders were prosecuted; 197 structures illegal erected in forest land were demolished; over 48 tons of timber of various species, 9817 frames of cedar posts, doors and door frames, 12 power saws, and 12 drawn carts of donkeys were impounded while 498 bags of charcoal were recorded (Kenya Forest Service 2010). Based on these statistics in relation to the recorded rates of displeasure, if more measures to promote the motivation of the rangers are undertaken, immense and improved performance shall be attested.

\section{Work motivation and work performance}

Moldogaziev and Fernandez (2011) perceive a view that the performance of employees is strongly attributed to the magnitude at which the workforce is empowered and motivated. Besides salaries and job appraisals, KFS through the ENCOM Division structures and programs can undertake various incentives that would promote the motivation of the rangers. Drawing insights from this view, the study assessed the levels at which the rangers were satisfied with the motivation measures deployed by KFS, their supervisors, the communication abilities of the unit and the stress freeness of their working environment. Table 4 outlines the feedback of the respondents.

Out of the 32 respondents, $47 \%$ equally recorded to be demotivated and satisfied with the work motivation measures undertaken by KFS such as outdoor activities and competitions. This is an indication the service is averagely motivating the rangers through their activities. The respondents also noted $59 \%$ disregard rate of the motivation programs undertaken by their supervisors. This implies no matter what the efforts the general ENCOM units undertake if it is not applied equivalently to all forest stations and equally to all the rangers, the Division is prone to ever record ubiquitous performance. The motivation should be equitably stemming from both the professional cadre (forest managers) and the ENCOM commander, inspectors, and corporals. KFS is based on a vertical organizational structure, the equity in the motivation status is likely to enhance the performance of the rangers across all forest stations across the country (Envag Associates 2013). If the supervisors of forest station and the Rangers fail in implementing their duties, it is inevitable for the forest stations to experience ever-high rates of destruction of forest resources.

In addition to poor work and supervisor motivation, the working environment of the rangers was overwhelmingly considered as unconducive. Sixty-three percent of the respondents registered discontent with their working environment noting it to be stressful due to lack of proper working gear among others. Oswald (2012) study on the implication of the working environment on the performance of health care workers in Tanzania noted that poor and stressful working conditions as perceived by the employees are a coherent ingredient of poor performance. Oswald argues that creation of a supportive environment has the potency of enhancing the efficacy of the workers. It is of paramount importance for the Service to determine and mitigate the stressful elements perceived by the rangers to enable them to improve their forest enforcement and compliance responsibility scorecard. It is argued by Moldogaziev and Fernandez (2011) that the amiability of the working condition amicably correlates with job satisfaction and productivity. This study elucidated a very high rate of stress factors in the environment, hence calling for radical measures to improve the working conditions of the rangers.

On the other hand, the rangers acknowledged the communication capacities of the rangers to be efficient. Seventy-four of the respondents approved the communication channels and programs provided. If the Service can provide efficient communication, it has the potential for extending the same to other sectors. Kimani (2012) and Mathu (2007) point out that due to technological advancements, it is also prudent for the Forest Services and departments to adopt new communication technologies that can further improve the working efficacy of the rangers.

\section{Sensitiveness to Rangers' needs and concerns}

In every working environment, there are specific needs anticipated by the workforce that they value and greatly perceived to motivate their performance when met. For instance, Warchol and Kapla (2012) note that it is a need for the conservation and forest rangers to be in a group of at least three and with sufficient gears when taking patrol duties. The needs and concerns varied extensively from forest station to station which many stem from decency of housing to prosecution of offenders. With this view, the researchers assessed the degree to which KFS promotes teamwork and its sensitivity to the needs and concerns of the forest rangers.

Table 4. Extent at which forest rangers supervisors motivate them to improve their performance by providing timely and constructive communication

\begin{tabular}{lcccc}
\hline \multicolumn{1}{c}{$\begin{array}{c}\text { Rangers } \\
\text { response }\end{array}$} & $\begin{array}{c}\text { Work } \\
\text { motivation } \\
\text { \% }\end{array}$ & $\begin{array}{c}\text { Supervisor Communication Stress- } \\
\text { motivation } \\
\text { \% }\end{array}$ & $\begin{array}{c}\text { and work } \\
\text { performance }\end{array}$ & $\begin{array}{c}\text { free } \\
\text { \% }\end{array}$ \\
\hline Strongly disagree & 4 & 3 & 0 & 8 \\
Disagree & 55 & 44 & 26 & 55 \\
Strongly agree & 11 & 15 & 63 & 14 \\
Agree & 26 & 32 & 11 & 22 \\
Don't know & 4 & 6 & 0 & 0 \\
\hline
\end{tabular}

Table 5. Sensitivity of KFS to forest rangers' concerns and needs and promotion of teamwork

\begin{tabular}{lcc}
\hline Rangers response & Needs and wants $\%$ & Teamwork \% \\
\hline Disagree & 63 & 26 \\
Strongly Disagree & 0 & 4 \\
Strongly Agree & 7 & 26 \\
Agree & 30 & 37 \\
Don't know & 0 & 7 \\
\hline
\end{tabular}


Sixty-three percent of the respondents indicated that Kenya Forest Service is not sufficiently sensitive to the needs and wants of the rangers. Only $37 \%$ approved the efforts undertaken by the Service in meeting their requirements and concerns. In a study conducted in 2013, one of the respondents was noted to look forward to a time when all the KFS employees shall be treated equally. Three years later, the rangers were still expressing skewness in the manner in which the Service responds to their needs (Kenya Forest Service 2010). Harter et al. (2004) argue that when the needs of employees are met, they become more involved and enthusiastic, hence promoting work productivity. They as well note the aggravated enthusiasm among employees who consider their employers to be assertive to their concerns creates and promotes a sense of belonging, value, and growth. Employee satisfaction is an antecedent of employee engagement. It is worth noting that employees with a higher job gratification are susceptible to sustainable performance in the long run (Koontz 2007; Eliason 2006).

The ENCOM Division fairly supports and promotes teamwork among its officers; $63 \%$ of the respondents indicated there are motivated and encouraged to embrace teamwork while $30 \%$ held a contrary view. Collaboration among forest rangers is critical to their success. The rangers patrol and protect large tracks of forests, which require very extensive and coordinated collaboration amongst themselves and other stakeholders, hence fundamental to the protection programs (Onyango 2013; Kimani 2012; Eliason 2006; Oswald 2012). Kozlowski and Bell (2012) noted that encouraging teamwork stimulates the involvement of employees due to paradigm shift from individuality to collectivity, hence mutual commitment and accountability.

\section{Adequacy and quality of transport facilities and work equipment}

The study aimed at assessing the magnitude at which the transport facilities and working equipment influenced the performance of the rangers. It was undeniable that about two-thirds of the rangers perceived the transport and work equipment as inefficient and unsustainable.

The above findings are startling as the duties of the rangers revolve around patrol, an activity that requires coherent and efficient means of mobility and equipment such as sufficient firearms and ammunition to counter forest offenders who may have more sophisticated weapons. Sixty-five and sixty-six percent of the respondents discredited the sufficiency and quality of the means of transport and working equipment respectively. Insufficiency of vehicles precisely designed for patrol in the forest terrains makes it impossible for the Rangers to transport even the apprehended culprits and impounded property to police station for booking.

The findings affirm the results in the 2010 and 2013 reports on impacts on working environment on KFS employees (Envag Associates 2013). Poor means of mobility and work equipment increase the workload in the division, in that they can patrol small areas within their reach, leaving other areas vulnerable to exploitation
(Warchol and Kapla 2012; Onyango 2013). Transport means are also critical as an emergency response strategy as the rangers as expected to be standing by at any time due to emergencies such as fire and intelligence on imminent and ongoing illegal activities (Onyango 2013). The 2013 study results also indicated that ENCOM staff has a satisfaction index of $48.89 \%$ and $41.67 \%$ on the adequacy of working tools (firearms, tents, GPS, and other surveillance equipment) and communication equipment (walkie-talkies) respectively (Envag Associates 2013). Lack of these facilities and equipment is a dire impediment to the operations assumed by the staff.

The activities of forest rangers majorly include forest patrols, which predominantly move through the forests. The primary pillars of their work efficiency are bestowed on their mobility potential as well as the work equipment such as firearms and camouflaging uniforms (Onyango 2013). Kimani (2012) points out that the operational efficacy of the forest rangers is rooted in the aptness of transport and work equipment facilities that directly implicate the Rangers actions as they undertake the prevention, detection, and suppression duties. Through activities such as patrols, prevention of forest crimes is combated as they aim at minimizing the opportunities of engaging in illegal acts, so the Rangers need to be able to swiftly move into the forests without detection by adjacent communities who may warn the offenders. The impounded products also need to be transported to the forest stations/beats and police stations; therefore, the inefficient means of transport make their duties futile and predetermined by offenders (Onyango 2013). The Rangers also need to be moved to certain points in the forest before they set on foot patrols to enhance the area covered in each patrol as opposed to walking from their bases into the forests. Onyango's (2013) study indicated that most of the forest stations in the Embu ecosystem in Kenya lacked vehicles in good conditions, hence impeding even the transportation of the arrested offenders to the police stations. The same was noted in this study, only the Masaita forest station and the Kericho Ecosystem base owned vehicles, while the other two depended on the Ecosystem's Conservators office to avail them with vehicles when needed. Consequently, poor working equipment such as raincoats, gumboots, and tents among others renders the work of the ranger's absolute cumbersome at night and during rainy days. These implications are advantageous to the offenders.

\section{Adequacy and quality of uniforms, living conditions, and equity issues}

Uniforms, living conditions, and cases of job discrimination against disciplined forces in Kenya attract a lot of attention (Onyango 2013). In this view, it was imperative to understand and evaluate the forest rangers' satisfaction with the adequacy and quality of their living conditions, uniforms, and equity issues.

The results show that the camouflage/jungle and official uniforms issued to the rangers are appropriate and of high quality. Sixty percent of respondents approved the uniforms while $40 \%$ viewed them to be inappropriate. Nevertheless, 
most registered substantial trepidations on the frequency at which uniforms are issued. Twenty-five point nine percent of the respondents preferred the uniforms to be issued whenever they are worn out, $22.2 \%$ after every two years, $14.8 \%$ after every five years, while the majority $(37 \%)$ desired the uniforms to be issued yearly.

The living condition of the forest rangers recorded the highest rate of displeasure; majority of the rangers $(78 \%)$ termed the living condition to be archaic, inhabitable and deplorable. Most of the houses are made of timber during the colonial era and lacked electricity and water, and neither are they regularly maintained. Kimani (2012) registered displeasure with the archaic status of the houses of the rangers. He argues that provision of better living conditions is an essential work motivation factor that the KFS has overlooked for so long hence beheading the rangers morale. KFS should prioritize improving the housing conditions of the rangers by constructing better and decent housing units as well as renovating the existing permanent structures. The working environment proved equitable and non-discriminating; $85 \%$ of the respondents appreciate the efforts of KFS in ensuring they are treated equally and fairly.

\section{Work-personal life balance}

The study noted that $97 \%$ of the respondents are able to keep a reasonable balance between their work and their personal life; thus, the balance does not limit their performance. In addition to personal life-work balance, $59 \%$ of responses showed the ranger is free to discuss their personal life and professional problems with their supervisors without fear of victimization.

Table 6. Adequacy and quality of the transport facilities and working equipment

\begin{tabular}{lcc}
\hline Rangers response & Transport \% & Working equipment \% \\
\hline Strongly disagree & 9 & 11 \\
Disagree & 56 & 55 \\
Strongly agree & 13 & 8 \\
Agree & 22 & 26 \\
\hline
\end{tabular}

Table 7. Responses on the appropriateness and quality of uniforms

\begin{tabular}{lccc}
\hline Rangers response & Uniforms \% & Living \% & $\begin{array}{c}\text { Discrimination } \\
\text { \% }\end{array}$ \\
\hline Disagree & 40 & 63 & 11 \\
Strongly disagree & 0 & 15 & 4 \\
Strongly agree & 4 & 7 & 30 \\
Agree & 56 & 15 & 55 \\
\hline
\end{tabular}

Table 8. Personal life - Work environment balance

\begin{tabular}{lcc}
\hline \multicolumn{1}{c}{ Rangers response } & Balance\% & Freeness\% \\
\hline Strongly disagree & 0 & 4 \\
Disagree & 3 & 37 \\
Strongly agree & 20 & 15 \\
Agree & 77 & 44 \\
\hline
\end{tabular}

\section{Conclusion and recommendations}

From the data analysis and the discussion above, it is evident that the performance of forest rangers in respect to the findings of this study is deteriorating at an alarming rate. The dissatisfaction rates of $59 \%$ and $63 \%$ in most of the parameters of the study indicate that their performance is compromised by many factors. Comparison of the finding of this study with the findings of the surveys of 2010 and 2013 depicts a large disparity, the dissatisfaction index of this study ranges between $59-63 \%$ compared to $51.4 \%$ and $56.74 \%$ satisfaction index of 2010 and 2013 surveys respectively (Kenya Forest Service 2010; Envag Associates 2013). The ENCOM Division has a huge responsibility to protect forests in Kenya; hence, a record of such low rates of satisfaction should worry every forest manager, conservationist, and policy-makers since the Rangers play an imperative role in the enhancing sustainability of future forests. Forest illegal activities in natural forests such as charcoal making and illegal logging have been on the rise, an indication of the poor performance of forest rangers because of the impoverished working conditions as noted in this study.

ENCOM Division has direct responsibility and large task to improve the working conditions and environment of the rangers. No matter how efficient conservation and regeneration programs may be undertaken, while enforcement lags behind, the cumulative performance of the entire process shall ever record poor performance. Measures that are more radical must be undertaken to enhance the performance and productivity of rangers by motivating them as well as acknowledging impediments of low employee satisfaction on workforce performance.

Some of the measures KFS can partake to promote the functionality and performance of the ENCOM cadre comprise provision of modern patrol facilities such as air patrol facilities (choppers), vehicles, and motorbikes specifically designed for forest terrain. These will enable rangers to access remote and impermeable areas as well as cover large areas over a short time. Better and adequate communications and surveillance amenities (such as walkie-talkies, hotlines, GPSs and GIS training) must also be facilitated, as they will improve communication and collaboration abilities among the officers and community forest policing activities, hence boosting their abilities to curb ongoing illegal operations. In addition, it is crucial for the division to be liquidated with sufficient and appropriate working tools. The ranger should be provided with a rifle, sufficient ammunition, gumboots due to the terrain and weather of Mau Complex, well-conditioned tents, and camping facilities, as well as frequent issuance of uniforms among other facilities and equipment, deemed necessary.

KFS should also consider revising salaries and the remunerations rates offered in accordance with the national and international stipulated pay grades. If in agreement, it should devise other mechanisms and incentives that would escalate the Rangers' motivation such as job appraisal and promotions. The promotions should be conducted on an equal and fair basis with profound emphasis on the cumulative performance of each ranger, work experience, and levels of education. 
The housing conditions have recorded the highest distressing rate of dissatisfaction, KFS should make it a priority. It should, therefore, construct permanent and decent housing units as opposed to timber ones, frequently renovating the existing ones, and at least supply them with electricity and tap water. The Rangers should be regularly taken to seminars and refresher courses on which they can be trained in customer care and polish their performance as a token of motivation.

\section{REFERENCES}

Anderson A. 2013. Factors affecting employee performance. Demand Media, Kenya.

Drizin M. 2003. Worker loyalty is pretty low. United Press International: http://www.upi.com/Business_News/2003/09/01/Worker-loyaltyprettylow/UPI-98111062459018/

Eliason SL. 2006. Factors influencing job satisfaction among state conservation officers. Policing Intl J Police Strat Manag 29 (1): 6-18. DOI: $10.1108 / 13639510610648458$

Envag Associates. 2013. Work Environment Survey. A Report Presented To Kenya Forest Service, Nairobi

Gichora M, Bargerei R. 2015. Forestry Society of Kenya Holds Forest Policy Dialogue Meeting. The Forester: A quarterly magazine of the Kenya Forest Service, Nairobi.

Harter JK, Asplund JW, Fleming JH. 2004. Employee engagement and performance: a meta-analytic study of causal direction. Gallup Research Report, Gallup, New York.

Kenya Forest Act. 2007. "Part V - Enforcement," Kenya Forests Act 2005.

Kenya Forest Service. 2010. In The Forester. A quarterly magazine of the Kenya Forest Service. Kenya Forest Service, Nairobi.
Kenya Forest Service. 2012. Enforcement and Compliance Standard Operating Procedures (Sops) manual. Kenya Forest Service, Nairobi.

Kimani JN. 2012. "The Ranger I have become." The Forester issue No.6.A quarterly magazine of Kenya Forest Service. Kenya Forest Service, Nairobi.

Koontz, T. M. 2007. Federal and state public forest administration in the new millennium. Public Administr Rev 67 (1): 152-164. DOI: 10.1111/j.1540-6210.2006.00704.x

Kozlowski SWJ, Bell BS. 2012. Workgroups and teams in organizations. In: Weiner IB, Schmitt NW, Highhnouse S. (eds.). Handbook of Psychology, Industrial and Organizational Psychology. 2nd ed. John Wiley \& Sons, NJ.

Krejcie RV, Morgan DW. 1970. Determining sample size for research activities. Educat Psychol Measur 30 (3): 607-610. DOI: 10.1177/001316447003000308

Mathu W. 2007. Forest Law Enforcement and Governance in Kenya. Kenya Forest Service (KFS), Ministry of Environment and Natural Resources, Nairobi.

New York State Department of Environmental Conservation. 2012. Division of Forest Protection 2012 Annual Report. New York.

Onyango NI. 2013. Factors Influencing Performance of Forest Rangers in Kenya Forest Service: A Case of Embu Ecosystem, Kenya. Kenya Forest Service (KFS), Ministry of Environment and Natural Resources, Nairobi.

Oswald A. 2012. The Effect of Working Environment on Workers Performance: The Case of Reproductive and Child Health Care Providers in Tarime District [Thesis]. Muhimbili University, Health and Allied Sciences, Kenya.

Van Herpen M, Van Praag M, Cools K. 2005. The effects of performance measurement and compensation on motivation: An empirical study. De Economist 153 (3): 303-329. DOI: 10.1007/s10645-005-1990-z

Warchol G, Kapla D. 2012. Policing the wilderness: A descriptive study of wildlife conservation officers in South Africa. Intl J Compar Appl Crim Justice 36 (2): 83-101. DOI: 10.1080/01924036.2012.669911

World Bank. 2018. Strengthening forest law enforcement and governance: addressing a systemic constraint to sustainable development. Institutional and Governance Review (IGR), Report Number 36638. World Bank, Washington, DC. 